\title{
Effects of Heat of Vaporization and Octane Sensitivity on Knock-Limited Spark Ignition Engine Performance
}

\author{
Matthew A. Ratcliff, Jonathan Burton, Petr Sindler, Earl Christensen, Lisa Fouts, and \\ Robert L. McCormick National Renewable Energy Laboratory
}

Citation: Ratcliff, M.A., Burton, J., Sindler, P., Christensen, E. et al., "Effects of Heat of Vaporization and Octane Sensitivity on Knock-Limited Spark Ignition Engine Performance," SAE Technical Paper 2018-01-0218, 2018, doi:10.4271/2018-01-0218.

\section{Abstract}

nock-limited loads for a set of surrogate gasolines all having nominal 100 research octane number (RON), approximately 11 octane sensitivity (S), and a heat of vaporization (HOV) range of 390 to $595 \mathrm{~kJ} / \mathrm{kg}$ at $25^{\circ} \mathrm{C}$ were investigated. A single-cylinder spark-ignition engine derived from a General Motors Ecotec direct injection (DI) engine was used to perform load sweeps at a fixed intake air temperature (IAT) of $50^{\circ} \mathrm{C}$, as well as knock-limited load measurements across a range of IATs up to $90^{\circ} \mathrm{C}$. Both DI and pre-vaporized fuel (supplied by a fuel injector mounted far upstream of the intake valves and heated intake runner walls) experiments were performed to separate the chemical and thermal effects of the fuels' knock resistance. The DI load sweeps at $50^{\circ} \mathrm{C}$ intake air temperature showed no effect of HOV on the knocklimited performance. The data suggest that HOV acts as a thermal contributor to $\mathrm{S}$ under the conditions studied.
Measurement of knock-limited loads from the IAT sweeps for DI at late combustion phasing showed that a $40 \mathrm{vol} \%$ ethanol (E40) blend provided additional knock resistance at the highest temperatures, compared to a 20 vol\% ethanol blend and hydrocarbon fuel with similar RON and S. Using the prevaporized fuel system, all the high $S$ fuels produced nearly identical knock-limited loads at each temperature across the range of IATs studied. For these fuels RON ranged from 99.2 to 101.1 and $S$ ranged from 9.4 to 12.2 , with E40 having the lowest RON and highest $S$. The higher knock-limited loads for E40 at the highest IATs examined were consistent with the slightly higher $\mathrm{S}$ for this fuel, and the lower engine operating condition $K$ values arising from use of this fuel. The study highlights how fuel HOV can affect the temperature at intake valve closing, and consequently the pressure-temperature history of the end gas leading to more negative values of $K$, thereby enhancing the effect of $S$ on knock resistance.

\section{Introduction}

\footnotetext{
$T$
}

here is a significant opportunity to improve sparkignition (SI) engine efficiency through the combined application of more efficient engine designs and operating strategies, and improved fuels [1]. The benefits of improved SI engine efficiency are enhanced national security through reduction of dependence on petroleum imports [2], reduced costs to consumers [3] , and protection of the environment [4]. In the United States and around the world, governments are requiring significant vehicle fuel economy improvements to achieve these benefits $[\underline{5}, \underline{6}]$.

The primary fuel related engine design and operational strategies that improve efficiency are increased compression ratio (CR), the combined effects of engine downsizing and turbocharging, operating the engine at lower speeds, cylinder deactivation, exhaust gas recirculation (EGR), and utilizing direct injection (DI) $[1,7, \underline{7}]$. Increasing CR increases the thermodynamic efficiency of the engine [9], while also increasing the temperature and pressure of the unburned fuel-air mixture resulting in engine knock at high loads. Thus, while increasing CR can be used to improve part load efficiency, it is limited by the knock resistance of the fuel. Engines exhibit lower efficiency when operated at light loads because of parasitic losses. Downsizing, turbocharging, and DI are used to operate engines at higher load over a larger portion of the engine map [10]. Similarly, operating at lower engine speeds or downspeeding requires higher load to achieve the same power. Downsizing and down-speeding also reduce friction in the engine resulting in improved efficiency. Cylinder deactivation is used at light loads to increase the load and hence efficiency in the remaining cylinders [11]. All these strategies to operate the engine at higher loads also result in higher temperature and pressure of the unburned fuel-air mixture, and thus are limited by engine knock.

Spark-timing retard is applied at high load conditions to mitigate knock but at the expense of reduced efficiency due to less ideal combustion phasing, reduced torque, and increased exhaust temperature [12]. At very high loads fuel enrichment is also used to reduce knock and control exhaust temperature to prevent engine and catalyst damage - but at the expense of high carbon monoxide and hydrocarbon emissions [13].

The high-efficiency engine design and operation strategies described above can all be pursued more aggressively-that 
is, with less use of spark timing retard and fuel enrichment-if the engine is using a more highly knock resistant fuel. For example, an analysis of several studies suggests that an increase of $1 \mathrm{CR}$ unit requires a research octane number (RON) increase of approximately 5 units [14]. Fuel properties that affect knock resistance include RON, motor octane number $(\mathrm{MON})$, octane sensitivity $(\mathrm{S}=\mathrm{RON}-\mathrm{MON})$, and heat of vaporization (HOV). Modern engines, especially downsized boosted engines, operate under conditions where increased RON and increased S (or decreased MON) cause increased knock resistance $[15,16]$. This effect has been described in terms of octane index (OI)-a fuel's actual resistance to autoignition [17]-where:

$$
\mathrm{OI}=\mathrm{RON}-K * S
$$

For downsized boosted engines $K$ is negative at the most knock-limited operating conditions, such that increasing $S$ increases OI [18].

While retaining stoichiometric conditions, EGR improves efficiency by reducing pumping losses at light and intermediate loads and by reduced heat transfer because of lower peak temperature [7]. The specific heat ratio $\mathrm{Cp} / \mathrm{Cv}$ (or $\gamma$ ) also increases with EGR which improves the efficiency of the conversion of heat into work. Also, Alger and coworkers have shown that the lower in-cylinder temperature caused by EGR reduces engine knock and that each percentage increase in EGR is equivalent to an octane number increase of 0.5 [ 8$]$.

DI enables higher power density in downsized boosted engines primarily by reducing the fuel-air mixture temperature through evaporative cooling $[19, \underline{20}, \underline{21}, \underline{22}, \underline{23}]$. These studies suggest that cooling for hydrocarbon fuels provides the same effect as an increase of roughly 5 octane number units-adequate to allow increasing compression ratio by 1 unit [15]. Evaporative cooling also improves engine volumetric efficiency by reducing pumping losses at part load [19]. Ethanol exhibits a much higher HOV than hydrocarbon gasolines, and thus ethanol blends can produce a significant increase in evaporative cooling and measured fuel knock resistance [19, $\underline{21}, \underline{22}, \underline{23}, \underline{24}, \underline{25}, \underline{26}, \underline{27}]$. Kasseris and Heywood present experiments and analysis showing that charge cooling can range from roughly $15^{\circ} \mathrm{C}$ for $\mathrm{E} 0$ to $30^{\circ} \mathrm{C}$ at E50 and as high as $50^{\circ} \mathrm{C}$ for E85 blends, and that these values are about $70 \%$ of the thermodynamic maximum possible cooling [22].

An important study by Foong and coworkers revealed the impact of evaporative cooling from ethanol blending on the RON measured in the Cooperative Fuels Research (CFR) engine by ASTM D2699 [28]. These researchers found little impact of increased HOV on RON up to approximately 30 to 40 volume percent (vol\%) ethanol, but at higher HOV levels RON was significantly higher relative to values measured using a modified test method with heating of the intake air to remove the HOV effect. The authors suggest that at ethanol levels above about $30 \%$, HOV cooling is so large that the intake mixture becomes saturated and liquid droplets are being inducted into the CFR engine. This study has been interpreted by others (but not by the original study authors) as indicating that the RON test captures the increased HOV from ethanol blends, and is supported by DI engine studies of fuels having differing ethanol content but matched RON where no additional knock resistance was observed $[\underline{13}, \underline{29}, \underline{30}]$. Yet these studies conflict with other studies cited above, and with the well-established effect of evaporative cooling in DI engines and the greater degree of cooling observed for ethanol blends.

Sluder and coworkers [25] addressed this apparent contradiction by pointing out that in studies showing an HOV benefit, HOV is covariant with S $[\underline{22}, \underline{23}, \underline{26}]$. However, studies that fixed $S$ while varying HOV did not show additional knock benefit for higher HOV fuels $[13,25, \underline{31}]$. Based on these studies, Sluder and coworkers suggest that HOV be considered as a thermal component to $\mathrm{S}$. However, $\mathrm{S}$ has a different effect on knock resistance at different engine operating conditions and this may also be true for HOV. The work described here is part of a larger effort to characterize the HOV of gasoline blends, examine the effect of HOV on knock and emissions at various engine conditions, and potentially learn how to leverage HOV to improve engine performance using specific operation strategies.

\section{Methods}

\section{Research Fuel Properties}

Table 1 details key properties of the fuels used in this study. Renewable oxygenates were blended into surrogates for gasoline blend-stock for oxygenate blending (BOBs) based on toluene, isooctane, and n-heptane. Surrogate BOBs were chosen to facilitate the design of fuel blends to target $100 \mathrm{RON}$, approximately $11 \mathrm{~S}$, and a range of HOVs, using information from blending studies by Foong et al. [32] and Morgan et al. $[\underline{33}]$. The two-component oxygenate blend E20 + 2\% p-cresol was chosen to build on results of previous studies of drop-in gasoline fuels by Ratcliff et al. [34] and McCormick et al. [35], using blending RON values developed in those studies to design the blend. Isooctane was used as a benchmark fuel, while toluene standardization fuel (TSF) having a nominal RON of 99.8 (TSF99.8)-the terminology and composition come from ASTM D2699 and D2700-provided a strictly hydrocarbon fuel with high $S$ and low HOV. The compositions of TSF and the TRF blends used for blending with oxygenates are shown in Table 2. The Fuels for Advanced Combustion Engines (FACE) gasoline B is a highly paraffinic, narrow distillation range research gasoline developed by the Coordinating Research Council [36]. It was blended with $25 \mathrm{vol} \%$ ethanol (E25-FACE B) to provide a higher-octane number benchmark for the study. RON and MON were

TABLE 1 Properties of the fuel blends (HOV at $25^{\circ} \mathrm{C}$ ).

\begin{tabular}{|c|c|c|c|c|c|}
\hline Fuel & RON & $\mathbf{S}$ & $\begin{array}{l}\text { HOV } \\
(\mathrm{kJ} / \mathrm{kg})\end{array}$ & $\begin{array}{l}\text { Oxygenate } \\
\text { (vol\%) }\end{array}$ & $\begin{array}{l}\text { Oxygen } \\
\text { (wt\%) }\end{array}$ \\
\hline Isooctane & 100 & 0 & 303 & 0 & 0 \\
\hline TSF99.8 & 100.4 & 11.3 & 390 & 0 & 0 \\
\hline $\begin{array}{l}\text { E20 + 2\% } \\
\text { p-Cresol-TRF88 } \\
\text { (E20) }\end{array}$ & 101.1 & 9.4 & 472 & $19.7+1.5$ & 7.4 \\
\hline E40-TRF69 (E40) & 99.2 & 12.2 & 595 & 39.4 & 14.0 \\
\hline E25-FACE B & 105.6 & 11.8 & 485 & 23.7 & 9.16 \\
\hline
\end{tabular}

(c) 2018 SAE International; Ford Motor Company; National Renewable Energy Laboratory. 
TABLE 2 Surrogate BOB, standardization fuel and gasoline compositions from detailed hydrocarbon analysis by ASTM D6729, before oxygenate blending.

\begin{tabular}{|c|c|c|c|}
\hline & $\begin{array}{l}\text { Toluene } \\
\text { (vol\%) }\end{array}$ & $\begin{array}{l}\text { Isooctane } \\
\text { (vol\%) }\end{array}$ & $\begin{array}{l}\text { n-Heptane } \\
\text { (vol\%) }\end{array}$ \\
\hline $\begin{array}{l}\text { TSF99.8 (nominally } \\
74 \text { vol\% toluene in } \\
\text { PRF38.5) }\end{array}$ & 73.6 & 10.3 & 16.1 \\
\hline $\begin{array}{l}\text { TRF88 (nominally } 30 \text { vol\% } \\
\text { toluene in PRF70) }\end{array}$ & 28.3 & 50.4 & 21.2 \\
\hline $\begin{array}{l}\text { TRF69 (nominally } 40 \text { vol\% } \\
\text { toluene in PRF32) }\end{array}$ & 41.2 & 18.5 & 40.3 \\
\hline FACE B & $5.9^{a}$ & $86.3^{b}$ & $7.5^{c}$ \\
\hline
\end{tabular}

measured by ASTM D2699 and D2700, respectively. Based on detailed gas chromatographic analysis using ASTM D6729, the total HOV was calculated as detailed in reference [24].

\section{Single-Cylinder Engine Experiments}

Specifications for the single-cylinder engine are listed in Table 3. This research engine was developed from a 2009 model year General Motors Ecotec 2.0 L LNF-series engine, with a side-mounted DI combustion system. The dynamometer, engine control, air handling, fuel supply, combustion analysis, and emission measurement systems have been previously described $[\underline{34}, \underline{37}]$. The single-cylinder engine was additionally modified with an upstream fuel injector (UI) using the same injector type as installed in the cylinder head. This injector was mounted $0.66 \mathrm{~m}$ upstream of the intake port and heat tape was wrapped on the intake runner wall. A thermocouple was mounted to the external surface of the intake wall and this temperature was controlled to $120^{\circ} \mathrm{C}$ to assist fuel evaporation in UI mode. This allowed the engine to be operated with pre-vaporized fuel, thereby negating the charge cooling effects from in-cylinder fuel evaporation that take place in DI mode. Intake air temperature (IAT) was controlled based on a temperature measurement at the intake port, downstream of the UI and heated intake runner. When changing fuels, a standard procedure was used for purging the fuel system, followed by running the engine at $2500 \mathrm{rpm}$ and 9 bar net mean effective pressure (NMEP) for 30 minutes.

All experiments were performed at $1500 \mathrm{rpm}$ using a start of injection at $-280^{\circ}$ after top dead center (aTDC), intake valve

TABLE 3 Single-cylinder engine specifications.

\begin{tabular}{|c|c|}
\hline Displacement (L) & 0.5 \\
\hline Bore $(\mathrm{mm})$ & 86.0 \\
\hline Stroke $(\mathrm{mm})$ & 86.0 \\
\hline Connecting rod length (mm) & 145.5 \\
\hline Piston pin offset (mm) & 0.8 \\
\hline Compression ratio & 9.2 \\
\hline Number of valves & 4 \\
\hline Combustion System & Side-mounted DI \\
\hline
\end{tabular}

(c) 2018 SAE International; Ford Motor Company; National Renewable Energy Laboratory. closing at $-134^{\circ}$ aTDC, and $\lambda=1.0-1.01$. A valve overlap of $24^{\circ}$, beginning at intake valve opening $\left(-355^{\circ}\right.$ aTDC), was chosen to reduce trapped residuals. Note that residual gas fraction should be near zero at all knock-limited conditions studied, because intake manifold pressure was always higher than exhaust pressure during the valve overlap period, so there was no driving force to trap residual exhaust. Start of injection at $-280^{\circ}$ was previously shown to minimize PM emissions from this engine at $1500 \mathrm{rpm}$, and by inference to avoid or minimize fuel impingement on the piston or cylinder wall [37]. Air flow was measured using a critical flow orifice system and fuel flow using a mass flow meter, as previously described [37].

Two types of engine experiments were performed. The first were load sweeps from 7 to 19 bar NMEP, beginning with maximum brake torque (MBT) spark timing, then retarding the combustion phasing as necessary to control knock. Load sweeps were performed at a fixed IAT of $50{ }^{\circ} \mathrm{C}$. The other experiments measured knock-limited loads as a function of IAT spanning $35^{\circ} \mathrm{C}$ to $90^{\circ} \mathrm{C}$ at retarded combustion phasing-a fixed crank angle for $50 \%$ mass fraction burned (CA50) of $20.5^{\circ}$ aTDC. These experiments were performed using both DI and UI modes of fueling to determine the effects of evaporative cooling from a given fuel's $\mathrm{HOV}$ on knock-limited performance. In the UI mode, the fuel was pre-vaporized before entering the combustion chamber, thus neutralizing the charge cooling that occurs when fuel is injected directly into the cylinder. Knock limits were based on a knock-integral (KI) calculation, using a value of 10 for the load sweeps. A lower KI of 7.8 was used for the IAT effects study to stay within the engine's maximum cylinder pressure limit of $10,000 \mathrm{kPa}$.

KI was calculated by the National Instruments (formerly Drivven) Combustion Analysis System (NI CAS) in near realtime. The method first filtered the in-cylinder pressure signal using a second-order Butterworth band-pass filter $(5-15 \mathrm{kHz}$ band), then rectified the filtered signal [38]. The knock window selected started at $5^{\circ}$ aTDC and lasted for $30^{\circ}$. The reference window started at $-210^{\circ}$ aTDC with $30^{\circ}$ duration. The filtered, rectified signal was then integrated for each of the knock and reference windows. The KI value was defined by:

$$
\mathrm{KI}=\int_{\text {Knock }} / \int_{\text {Reference }}-\text { Threshold }
$$

The threshold value chosen for this study was $0.5 \mathrm{KI}$ units.

NI CAS also provides post-processing for the raw data files. The bulk gas temperature calculation was based on the measured in-cylinder pressure (average of 100 cycles), slidercrank model computed volume and the temperature at intake valve closing (IVCT). The presence of any exhaust residual fraction and the effects this would have on the specific heat ratio (gamma) and IVCT were ignored. This was justified based on the determination that intake and in-cylinder pressures were always higher than exhaust pressure during the valve overlap period for knock-limited operation. For UI experiments IVCT was assumed equal to the controlled IAT. For DI experiments IVCT was computed from the ideal gas law using the known cylinder volume, measured pressure, and measured air and fuel flow rates. A single-zone model, without heat transfer, was used to compute the apparent heat 
release rates (AHRR) from the average in-cylinder pressure of 100 cycles $[\underline{39}, \underline{40}]$. Calculation of AHRR utilized a constant specific heat ratio of 1.34 for all cases.

\section{Results}

\section{Engine-Fuel Performance}

Figure 1 shows results for the DI load sweeps versus the CA50 metric for combustion phasing. The performance benefit from fuels that have $S \approx 11$ compared with isooctane $(S=0)$ is clear. A load of $1500 \mathrm{kPa}$ NMEP was the highest output achievable for isooctane because nearly $17^{\circ}$ of spark retard (relative to MBT spark timing) was required to control knock. The resulting late combustion phasing at CA $50 \approx 24^{\circ}$ aTDC just avoided combustion instability, which manifested as coefficient of variation $>2 \%$ for NMEP with more retarded CA50. In contrast, only $\approx 6^{\circ}$ of spark retard was required to control knock for the high S fuels at $1500 \mathrm{kPa}$ NMEP. Minimizing combustion phasing retard implies higher thermal efficiency because the phasing is closer to optimal (i.e., MBT). These results require that $K$ in equation (1) is negative at retarded spark timing. Note that even higher loads could be achieved from the high $S$ fuels by retarding combustion phasing further. However, an upper NMEP limit of $1900 \mathrm{kPa}$ was imposed because this load corresponded with peak cylinder pressures during knocking cycles at or near General Motor's recommended limit of 10,000 kPa; this threshold triggered an automatic attenuation of fuel injection rate to protect the engine.

The three $S \approx 11$ fuels all produced essentially the same performance, within experimental error. Thus, at these conditions, knock-limited performance appears to be independent of the fuels' HOV (ranging from $390 \mathrm{~kJ} / \mathrm{kg}$ to $595 \mathrm{~kJ} / \mathrm{kg}$ at $25^{\circ} \mathrm{C}$ ), suggesting that HOV effects on knock resistance are included in $\mathrm{S}$ under these operating conditions. This is

FIGURE 1 DI load sweeps versus CA50 combustion phasing at IAT $=50^{\circ} \mathrm{C}$ and $1500 \mathrm{rpm}$. MBT combustion phasing was maintained up to the knock-limit ( $\mathrm{KI}>10)$, and then spark timing was retarded to maintain this value of $\mathrm{KI}$ as load was increased.

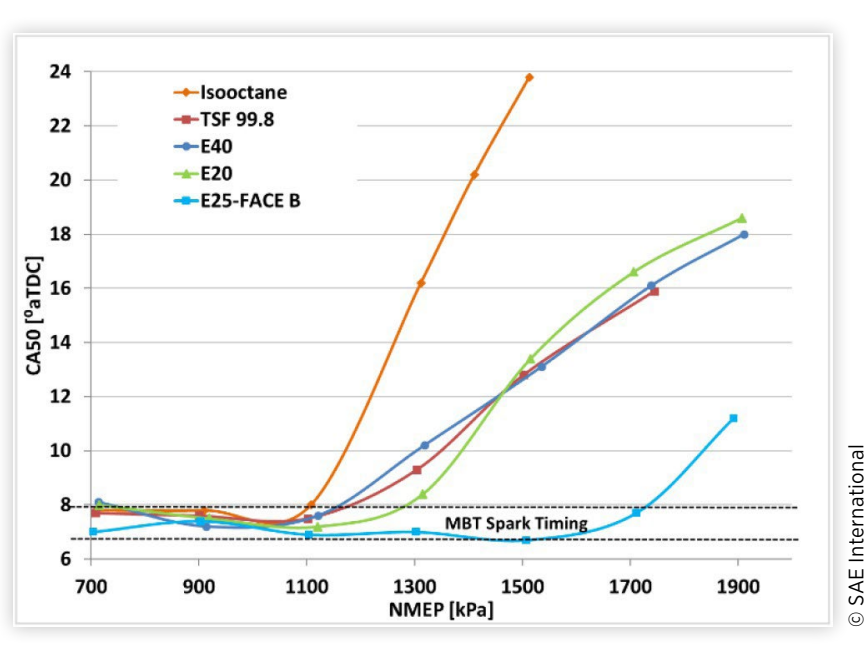

FIGURE 2 Results of IAT sweeps using both DI and UI modes at $1500 \mathrm{rpm}$ and CA50 held constant at $20.5^{\circ}$ aTDC. $\mathrm{Knock}$ limit defined as $\mathrm{KI} \geq 7.8$. Fuel HOV values shown are for $25^{\circ} \mathrm{C}$.

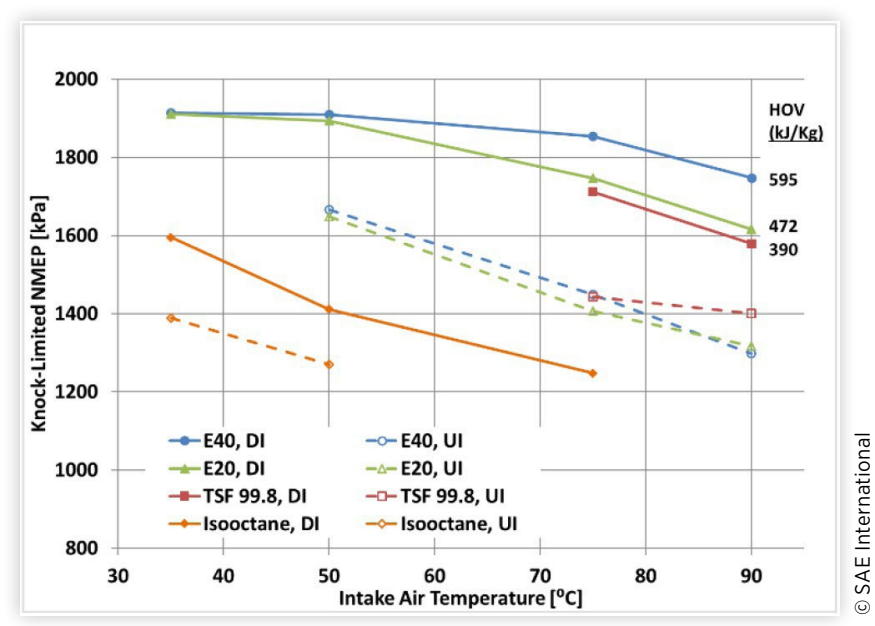

consistent with the theory of HOV being a thermal contributor to $S$ proposed by Sluder et al. [25].

Figure 2 shows NMEP across a range of IATs at late combustion phasing (CA50 held constant at $20.5^{\circ}$ aTDC) for both DI and UI fueling. Tables of the data presented in Figure 2, along with other parameters investigated, are shown in the appendix, Tables $\mathrm{A}-\underline{1}$ and $\underline{\mathrm{A}}-\underline{2}$. Comparing results for UI versus DI mode, much higher knock-limited load is achievable with DI because of charge cooling. For isooctane the increase in NMEP ranges from 100 to $200 \mathrm{kPa}$. For TSF99. 8 and E20 the average NMEP difference is about $200 \mathrm{kPa}$ at $50^{\circ} \mathrm{C}$, but increases to 250 to $300 \mathrm{kPa}$ at higher temperatures. For E40 the average NMEP increase for DI is over $400 \mathrm{kPa}$ at 75 and $90^{\circ} \mathrm{C}$ IAT. Comparing the high-S fuels with isooctane, much higher loads are obtained at all IAT values, indicating the $K$ in equation (1) is less than zero for all experiments reported in Figure 2. Finally, varying HOV had little effect on load in UI mode as the high-S fuels achieved approximately the same load at a given IAT.

The most significant observation from Figure 2 is the much higher NMEP achieved by $\mathrm{E} 40$ at $75^{\circ} \mathrm{C}(+125 \mathrm{kPa})$ and $90^{\circ} \mathrm{C}(+150 \mathrm{kPa})$ relative to $\mathrm{E} 20$ and TSF99.8. The E40 exhibited slightly higher $S$ than the other fuels, however $K$ is expected to become more positive as IAT increases suggesting that this effect should diminish. Significantly higher evaporative cooling of the intake charge would be expected for E40, but appears to have little effect at $50^{\circ} \mathrm{C}$ or lower IAT, consistent with the proposal that $\mathrm{HOV}$ is incorporated into $\mathrm{S}$.

\section{Combustion Analysis}

Cylinder pressure versus crank angle results for all experiments at $90^{\circ} \mathrm{C}$ IAT are shown in Figure 3. Results from other temperatures are shown in the appendix, Figures A1 - A3. Because CA50 is held constant, these plots are all very similar for a given IAT with almost identical crank angle for peak pressure, but show a decrease in pressure with reduced load. Apparent heat release rates versus crank angle are are shown 
FIGURE 3 Engine pressure data for $90^{\circ} \mathrm{C}$ IAT condition, CA50 fixed at $20.5^{\circ}$.

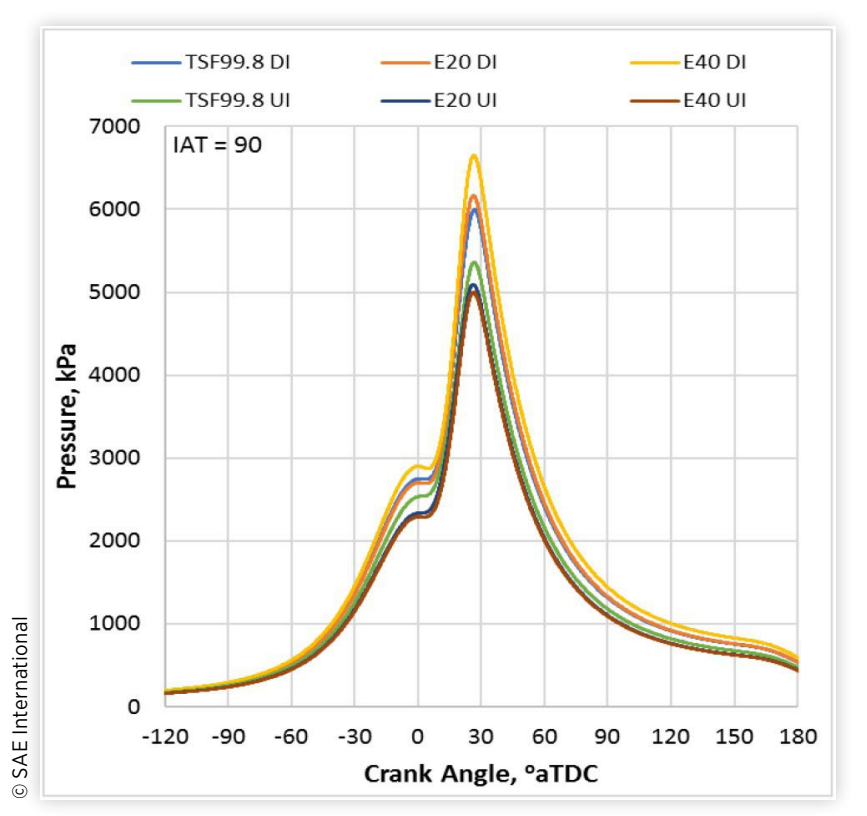

in Figure 4 for experiments at $90^{\circ} \mathrm{C} \mathrm{IAT}$, and in the appendix, Figures A4 - A6 for other conditions. Crank angle for peak heat release and combustion duration are very similar in all tests for these fixed CA50 conditions. As previously reported by Szybist and Splitter who used the same engine model but operated at $2000 \mathrm{rpm}$ and $20 \mathrm{bar}$ IMEP [41], we observe some evidence for pre-spark heat release for isooctane in UI mode at every IAT (see appendix) and for TSF99.8 in UI mode at IAT of $90^{\circ} \mathrm{C}$ (Figure $4 \mathrm{~b}$ ). This observation is not the focus of the current paper and is not discussed further.

The mixture pressure-temperature (P-T) trajectory is closely related to $K$ and thus to OI in equation (1). Bulk gas temperatures are a function of IVCT. Figure 5 shows pre-spark (or end of compression) temperatures for the fuels tested at $90^{\circ} \mathrm{C}$ IAT. In UI mode differences in gamma and air-to-fuel ratio lead to significantly lower end of compression temperatures for the ethanol blends than for TSF99.8. The steeply increasing temperature curve for TSF99.8 at end of compression is consistent with the idea that this fuel is beginning to react pre-spark. For DI mode end of compression temperatures are significantly lower. There is only a small difference between E20 and E40, however this is consistent with the difference in IVCT of $3 \mathrm{~K}$ for these fuels under these conditions.

The fuel HOV measurements and combustion stoichiometry can be used to estimate a theoretical maximum possible level of evaporative cooling [22]. The calculation must also reflect that HOV declines with increasing temperature as shown in Figure 6a. The calculation assumes that a stoichiometric quantity of fuel and air at IAT evaporates instantaneously with no heat transfer, and no wall wetting. Under these assumptions the adiabatic evaporative cooling, $\Delta \mathrm{T}_{\mathrm{ad}}$ is given by equation (3):

$$
\Delta \mathrm{T}_{\text {ad }}=\mathrm{m}_{\text {fuel }} * \mathrm{HOV} /\left(\left(\mathrm{m}_{\text {fuel }}+\mathrm{m}_{\text {air }}\right) * \mathrm{C}_{\mathrm{p} \text {-mixture }}\right)
$$

$\mathrm{m}_{\text {fuel }}$ is the mass of fuel, HOV is the heat of vaporization, $\mathrm{m}_{\text {air }}$ is the mass of air, and $\mathrm{C}_{\mathrm{p} \text {-mixture }}$ is the heat capacity at (c) 2018 SAE International; Ford Motor Company; National Renewable Energy Laboratory.
FIGURE 4 a) apparent heat release rate for all fuels at IAT $=90^{\circ} \mathrm{C}$ and $\mathrm{b}$ ) expanded view of pre-spark region. Spark at approximately $-1^{\circ}$ aTDC.
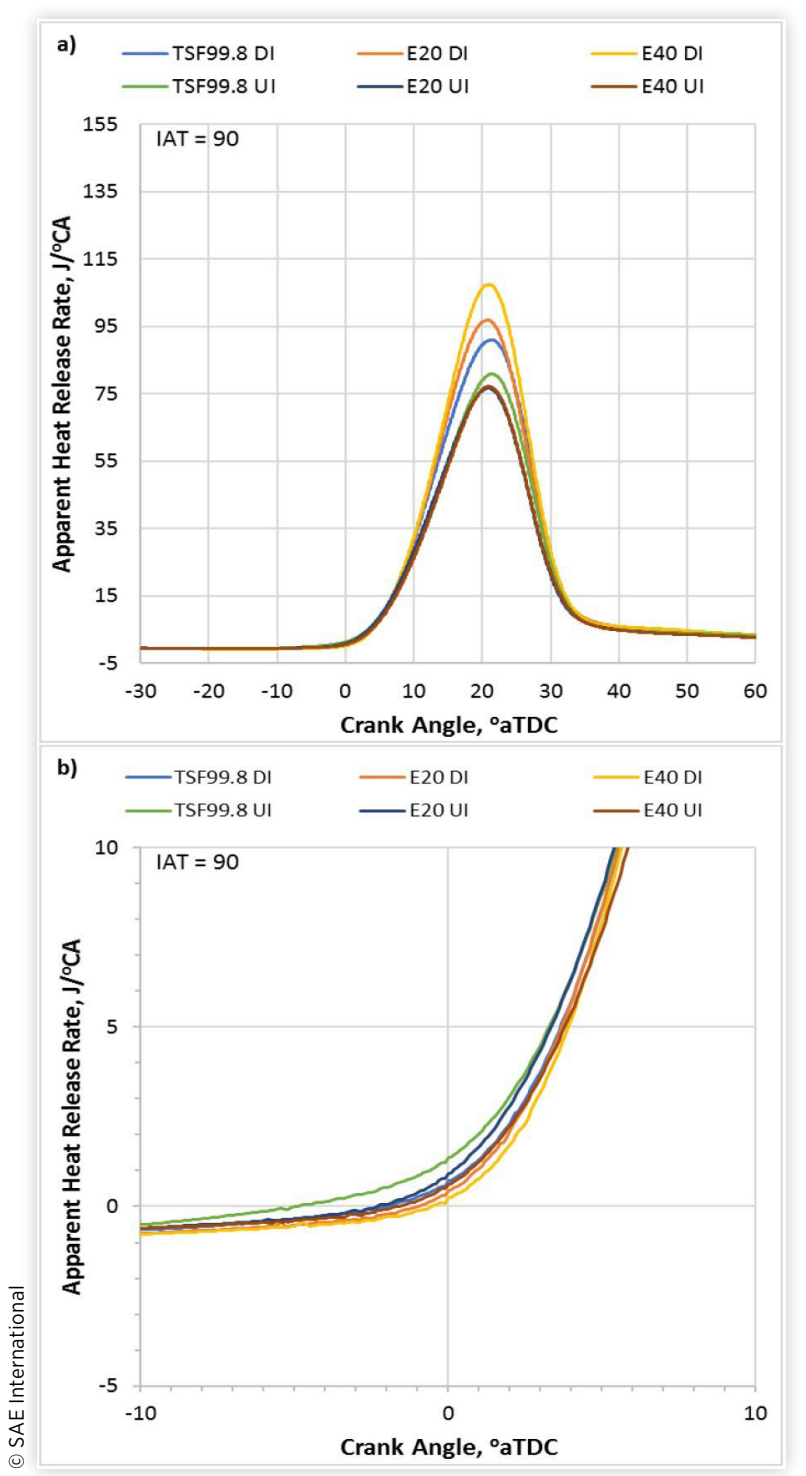

constant pressure of the fuel-air mixture. Calculated $\Delta \mathrm{T}_{\mathrm{ad}}$ results are presented in Figure 6b. While the fuels used here are surrogates containing only a few components rather than full boiling range gasolines, the calculated $\Delta \mathrm{T}_{\mathrm{ad}}$ values are consistent with full boiling range gasoline results presented in previous publications $[\underline{22}, \underline{24}]$.

Kasseris and Heywood, using the multi-cylinder version of the same GM engine model used here, estimated the evaporative cooling for DI compared to PFI by determining how much IAT needed to be increased in DI mode to achieve the same maximum pressure at knock onset as in PFI mode $[\underline{22}, \underline{23}]$. The temperature increase required ranged from 70 to $80 \%$ of $\Delta \mathrm{T}_{\mathrm{ad}}$ and was generally close to $70 \%$. Figure 7 compares IVCT from the ideal gas law based calculation with $100 \%$ of $\Delta \mathrm{T}_{\mathrm{ad}}$ for the DI experiments. For points that fall above the diagonal parity line, the IVCT from ideal gas calculation is colder than that from $\Delta \mathrm{T}_{\mathrm{ad}}$, while points below the diagonal are for ICVT from ideal gas that are hotter than those based 
FIGURE 5 Simulated bulk gas temperature for compression at $90^{\circ} \mathrm{C}$ IAT. Spark at approximately $-1^{\circ}$ aTDC.

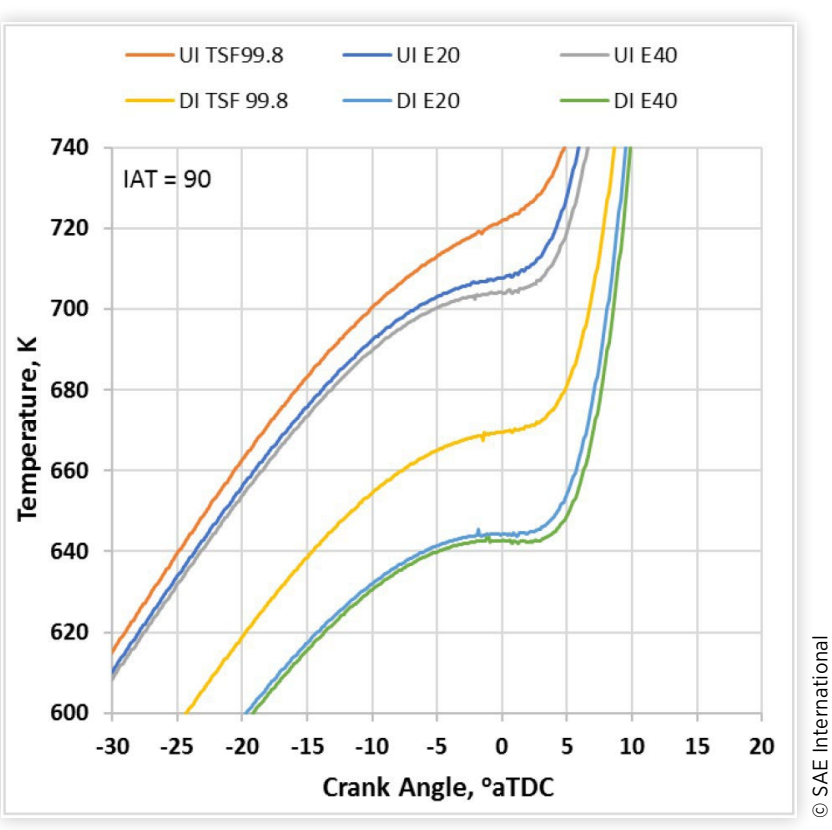

FIGURE 6 HOV as a function of temperature for the fuels tested in this study (a), and adiabatic evaporative cooling for stoichiometric fuel-air mixtures of these fuels (b).
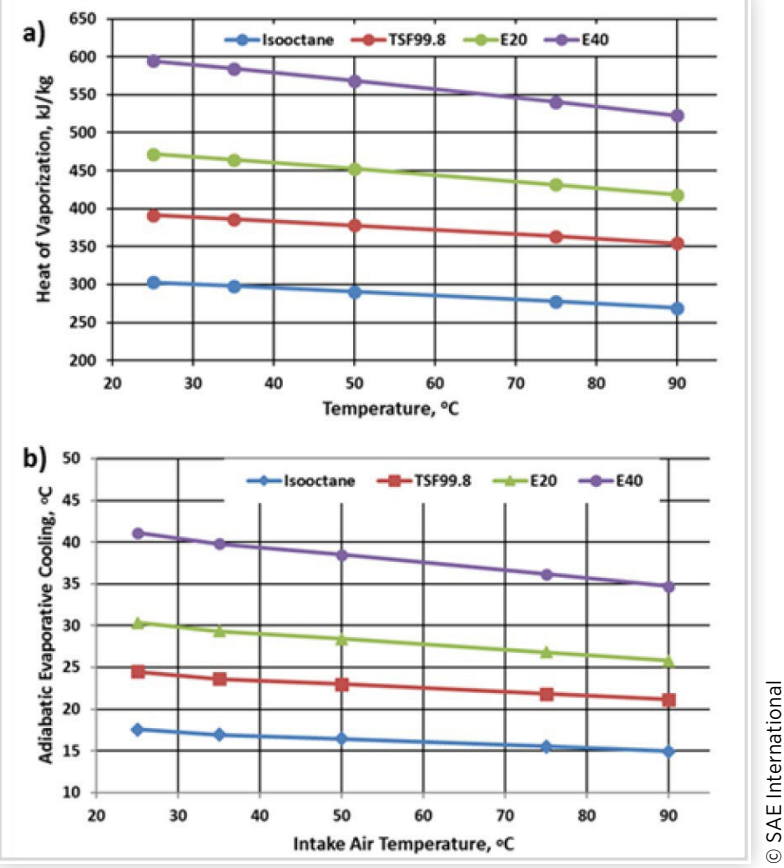

on $\Delta \mathrm{T}_{\mathrm{ad}}$. The lowest temperatures in Figure 7 are for the lowest IAT values. At low IAT $\left(50^{\circ} \mathrm{C}\right.$ and lower) the ideal gas law calculation predicts less evaporative cooling than $\Delta \mathrm{T}_{\mathrm{ad}}$. At IAT of $75^{\circ} \mathrm{C}$ the ideal gas calculation predicts cooling of approximately $100 \%$ of $\Delta \mathrm{T}_{\mathrm{ad}}$. For IAT of $90^{\circ} \mathrm{C}$, Figure 7 indicates that IVCT from the ideal gas law exhibits a slightly higher level of cooling than available for the adiabatic case. We have high confidence in our air flow measurement, so this
FIGURE 7 Comparison of intake valve closing temperatures for DI experiments calculated using the ideal gas law and those estimated from IAT and $\Delta T_{a d}$.

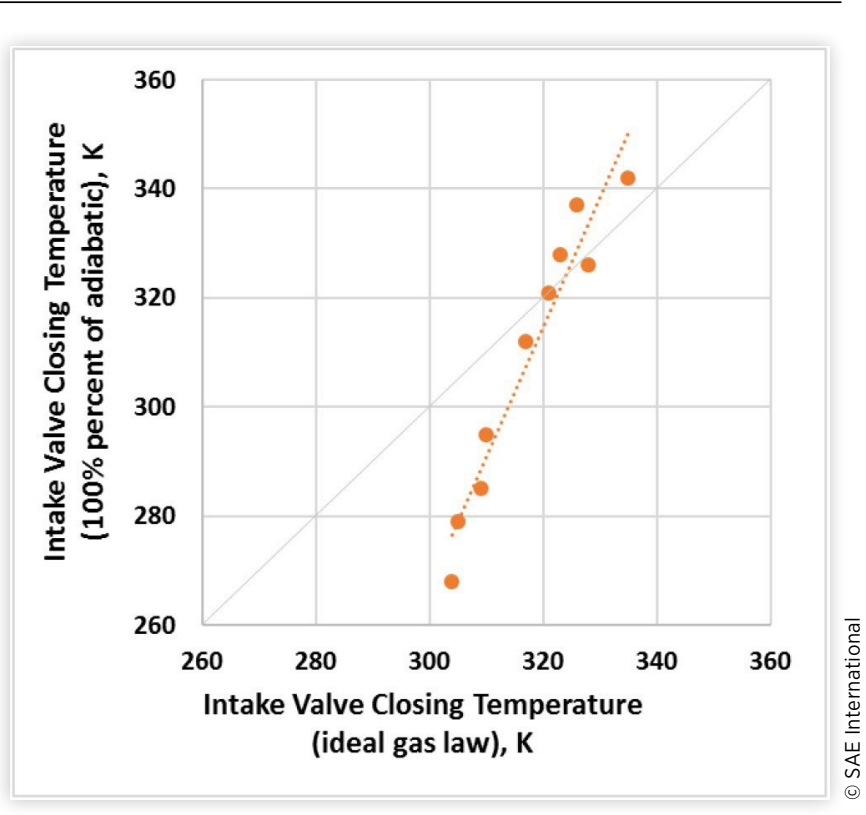

likely points to poor accuracy in measuring the fuel flow rates used in the calculation. The steep slope of the plotted data is consistent with the hypothesis that a higher fraction of $\Delta \mathrm{T}_{\mathrm{ad}}$ is attained a higher IAT because of more rapid evaporation of the fuel leading to less opportunity for heat transfer to engine surfaces $[\underline{22}, \underline{23}]$.

\section{Estimation of $\mathrm{K}$ and $\mathrm{OI}$}

Figure 8 shows the pressure-temperature (P-T) trajectories for the high-S fuels examined in this study at $90^{\circ} \mathrm{C}$ IAT, as well as the trajectory for the RON test. The RON trajectory was taken from [41] and is for $100 \mathrm{RON}$. These trajectories extend up to spark timing. As Figure 8 reveals, conditions for these experiments are at "beyond RON" conditions even for the highest IAT case, and therefore values of $K$ in equation (1) are expected to be negative - consistent with the observable effect of higher $S$ to increase fuel knock resistance.

The $K$ factor in equation (1) depends on the pressuretemperature history of the unburned gas, it is not a fuel property [17]. $K$ can be estimated from experimental data using a multiple linear regression approach that ideally requires a large set of fuels where RON and $S$ are not correlated [42]. Three of the four fuels tested here have nominally the same RON and S, violating the assumption for regression that independent variables be uncorrelated. Additionally, as we show below, $K$ is affected by evaporative cooling, leaving only the UI experiments as suitable for the multiple linear regression analysis approach. With only three data points available at each IAT, the data are not adequate for attempting this analysis. Several other approaches were examined, including the PRF method via interpolation [43] , but were also not workable using this dataset.

$K$ can also be approximately predicted from the temperature when the pressure reaches 15 bar $(1500 \mathrm{kPa})$ during the 
FIGURE 8 Pressure-temperature trajectories for compression compared to the RON test at IAT $=90^{\circ} \mathrm{C}$.

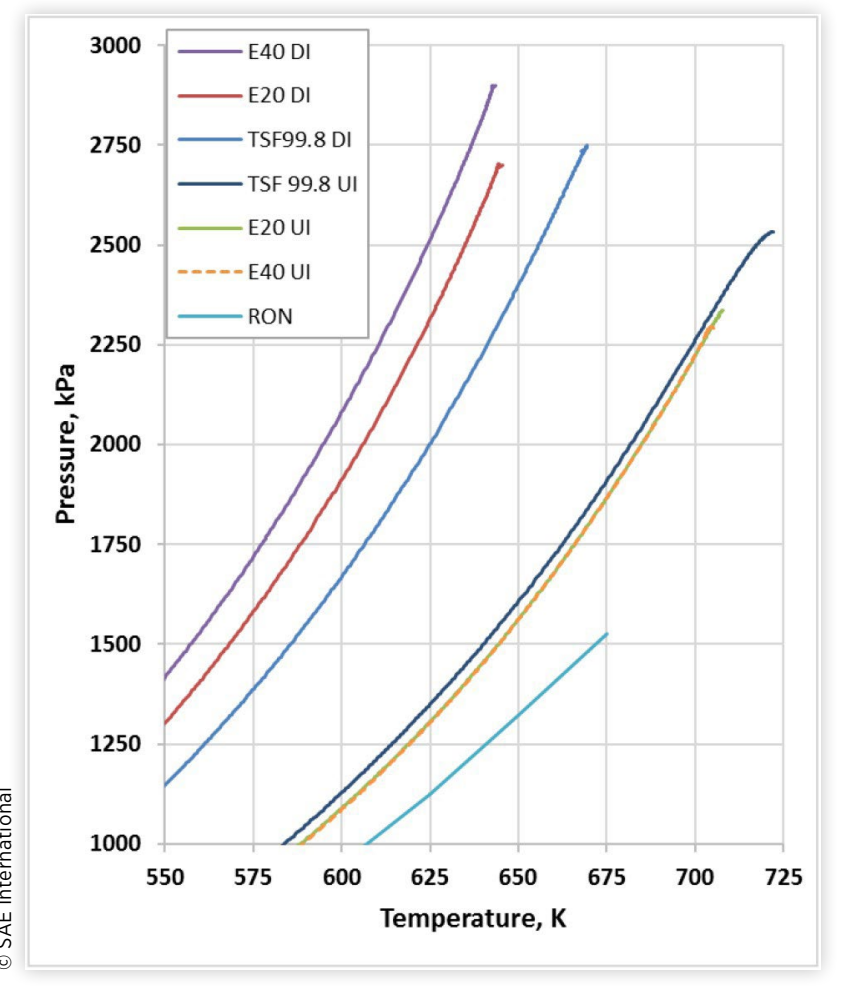

compression stroke $\left(\mathrm{T}_{\text {comp15 }}\right)$ as suggested by Kalghatgi [44]. Two equations were proposed based on lean mixture homogeneous charge compression ignition experiments - equations (4) and (5), valid for $\mathrm{T}_{\text {comp15 }}$ below $825 \mathrm{~K}$ :

$$
\begin{gathered}
K=0.0056\left(\mathrm{~T}_{\text {comp } 15}\right)-4.68 \\
K=0.00497\left(\mathrm{~T}_{\text {comp } 15}\right)-0.135 \lambda-3.67
\end{gathered}
$$

$\mathrm{T}_{\text {comp15 }}$ has been shown to be correlated with measured $K$ values for knocking engines as well $[\underline{45}, \underline{46}$, 47] although it is not applicable under all conditions [41]. However, a recent study using the same engine model as employed here found that equation (4) predicted physically reasonable values of $K$ that led to OI values that were well correlated with knocklimited CA50 [41]. These results were obtained at $2000 \mathrm{rpm}$, but at similar values of IAT and at loads both above and below those of the current study.

$\mathrm{T}_{\text {comp15 }}$ was calculated using IVCT based on the ideal gas law for DI cases, while UI cases assumed IVCT = IAT. Values of $K$ were calculated using both equation (4) and equation (5), and all calculated $K$ and OI values are shown in Tables A- 1 and $\underline{A}-\underline{2}$. Estimated $K$ ranged from -0.7 to -1.7 , in line with expectations. In a few cases the ideal gas calculation predicts IVCT lower than the adiabatic case. The worst case is $11 \mathrm{~K}$ more cooling than predicted from $\Delta \mathrm{T}_{\mathrm{ad}}$, which translates to at most a $10 \%$ difference in $K$ from equation 5 , and given the magnitude of $S$ relative to RON only a few percent difference in OI. $K$ calculated from equation (5) were about 0.5 units more positive than $K$ from equation (4), and produced better correlations between OI and knock-limited NMEP as shown in Figure 9.

(c) 2018 SAE International; Ford Motor Company; National Renewable Energy Laboratory.
FIGURE 9 Regression analyses for DI and UI cases of NMEP vs. OI for experiments conducted at different IAT, with CA50 $=20.5^{\circ}$ aTDC. OI based on equation 4 (K4) or equation $\underline{\underline{5}}(\mathrm{~K} 5)$.

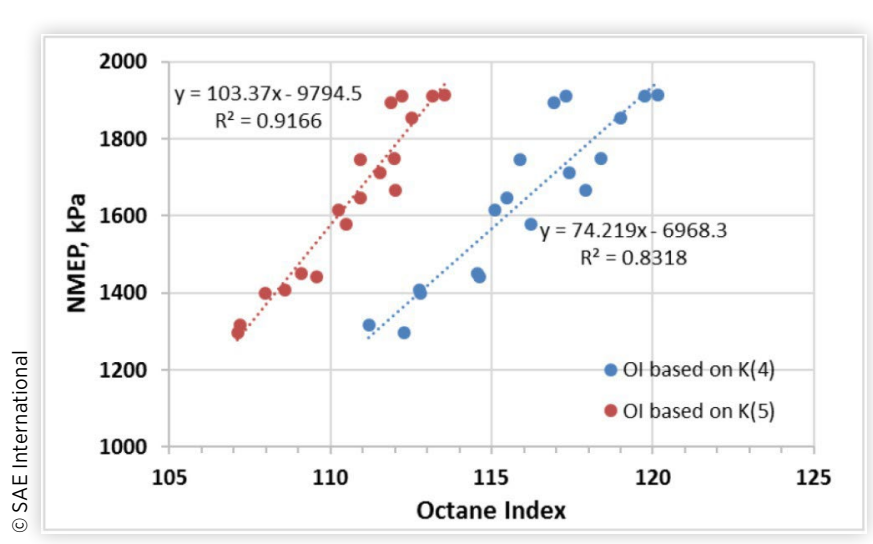

While the analysis leading to Figure 9 is based on estimated rather than measured values of $K$, the fact that knocklimited NMEP is reasonably well correlated with OI (using equation 5) supports the theory that HOV is a thermal component of $\mathrm{S}$ and thus captured in the RON test for blends up to approximately E40 (or to an HOV equivalent to that of E40) $[\underline{25}, \underline{28}]$. The reason higher loads were achieved using E40 at $75^{\circ} \mathrm{C}$ and $90^{\circ} \mathrm{C}$ IAT is the slightly higher $\mathrm{S}$ of this fuel coupled with the slightly lower $K$ produced by the larger degree of evaporative cooling. As shown in Table A-1, $K$ values are 5-15\% lower (more negative) and the $-K^{\star} \mathrm{S}$ term is $2-3.5 \mathrm{ON}$ units higher for $\mathrm{E} 40$ at $75^{\circ} \mathrm{C}$ and $90^{\circ} \mathrm{C}$, compared to TSF99.8 and E20.

\section{Discussion and Conclusions}

Higher HOV fuels in DI engines reduce the temperature at intake valve closing, at end of compression, and presumably in the end gas. The lower temperature achieved at a given pressure results in lower $K$, consistent with predictions from $\mathrm{T}_{\text {comp15. }}$. As noted, $K$ is a function of the P-T history of the end gas and is not primarily a fuel property [17]. However, end gas P-T history and thus $K$ necessarily depend on fuel composition and properties. Mixture composition, including the lower stoichiometric air-fuel mass ratio for oxygenates, affects gamma and moles of charge at intake valve closing, which will affect end gas temperature and pressure. And additionally for DI engines, HOV reduces IVCT which can significantly reduce $K$, enhancing the positive impact of $S$ on knock resistance for beyond RON conditions. Fuels with higher HOV such as ethanol blends will therefore have lower values of $K$, all other factors being equal.

The E40 fuel tested here exhibited $1 \mathrm{ON}$ unit higher $\mathrm{S}$ than the other fuels. This was magnified by the lower values of $K$ caused by this fuels higher HOV, yielding higher knock resistance at $75^{\circ} \mathrm{C}$ and $90^{\circ} \mathrm{C}$ IAT. It is an interesting question as to why the effect did not also increase knock resistance 
relative to the other nominally $\mathrm{S}=11$ fuels at $50^{\circ} \mathrm{C}$ or $35^{\circ} \mathrm{C}$ IAT. We believe that this is caused by the lower degree of evaporative cooling that is realized at these lower IAT values, as shown in Figure 7.

Foong and coworkers [28] showed that intake mixture temperatures (downstream of the carburetor) on the RON test ranged from about $36^{\circ} \mathrm{C}$ for hydrocarbon gasoline to about $20^{\circ} \mathrm{C}$ for $40 \mathrm{vol} \%$ ethanol blended into a hydrocarbon gasoline. Under the standard RON test conditions the effect of HOV appears to be captured, leading to higher RON and thus higher S. However, Kolodziej and Wallner showed that for RON tests with $\mathrm{E} 30$ blends the P-T trajectories were beyond RON relative to the PRF of the same RON value (trajectory showed lower temperatures at a given pressure) [48]. Thus, for RON testing of blends with significant ethanol content, $K$ is actually less than zero rather than the assumed (or defined) value of $K=0$ for the RON test. Foong and coworkers proposed a modified RON test wherein the IAT was heated to a level that maintained the intake mixture temperature at $36^{\circ} \mathrm{C}$ - the value observed for hydrocarbon gasoline. Taking the perspective that the modified RON test provides actual or true RON values (with $K=0$ ), and that the standard RON test allowing evaporative cooling to lower the intake mixture temperature provides OI values, the values of $K$ for the standard RON measurements can be calculated. Using Foong and coworkers' data for PRF100-ethanol blends [32], $K$ values of -0.05 and -0.16 are estimated for E20 and E40, respectively (Table A-3). The assumption that $K=0$ for the standard RON test with high HOV fuels, which reduce IVCT relative to hydrocarbon fuels, is the source of how HOV is captured as a thermal component of $S$, as previously proposed [25].

The results presented here are somewhat qualitative given the need to estimate $K$ from $\mathrm{T}_{\text {comp15 }}$ without experimental validation, and the precision of our measurement of the parameters that go into calculating IVCT. However they illustrate the complexities that arise when varying fuel HOV in $\mathrm{DI}$ engines, and even on the RON test in a CFR engine. Future work should focus in approaches for accurate and precise measurement of IVCT and to validation of $K$ predictions by direct measurement. It is also of interest to examine if fuels with higher HOV (higher ethanol content) than examined here produce results where HOV is not captured in S, or if different engine operational strategies intended to maximize the evaporative cooling effect can provide mixture cooling beyond that captured in RON or as a thermal component of $\mathrm{S}$. The potential role of fuel HOV in lean SI combustion, stratified charge combustion, and mixed-mode spark-compression ignition combustion should also be explored.

\section{References}

1. Leone, T.G., Anderson, J.E., Davis, R.S., Iqbal, A., et al., “The Effect of Compression Ratio, Fuel Octane Rating, and Ethanol Content on Spark-Ignition Engine Efficiency," Environmental Science and Technology 49:10778-10789, 2015.

2. United States Energy Information Administration, https:// www.eia.gov/tools/faqs/faq.php?id=32\&t=6, accessed Oct. 11, 2017.
3. United States Energy Information Administration, https:// www.eia.gov/todayinenergy/detail.php?id=19211, accessed Oct. 11, 2017.

4. Elgowainy, A., Han, J., Cai, H., Wang, M. et al., "Energy Efficiency and Greenhouse Gas Emission Intensity of Petroleum Products at U.S. Refineries," Environmental Science \& Technology 48(13):7612-7624, 2014.

5. U.S. Environmental Protection Agency, Department of Transportation, "2017 and Later Model Year Light-Duty Vehicle Greenhouse Gas Emissions and Corporate Average Fuel Economy Standards; Final Rule." Federal Register 77(199): 62623-63200, 2012.

6. The International Council on Clean Transportation, Global Passenger Vehicle Standards. http://www.theicct.org/infotools/global-passenger-vehicle-standards.

7. Caton, J.A., "A Comparison of Lean Operation and Exhaust Gas Recirculation: Thermodynamic Reasons for the Increases of Efficiency," SAE Technical Paper 2013-01-0266, 2013; doi:10.4271/2013-01-0266,

8. Alger, T., Mangold, B., Roberts, C., and Gingrich, J., “The Interaction of Fuel Anti-Knock Index and Cooled EGR on Engine Performance and Efficiency" SAE Int. J. Engines 5(3):2012, doi:10.4271/2012-01-1149.

9. Heywood, J.B., "Internal Combustion Engine Fundamentals," (New York, McGraw-Hill, Inc., 1988).

10. Yi, J., Wooldridge, S., Coulson, G., Hilditch, J., et al., "Development and Optimization of the Ford 3.5L V6 EcoBoost Combustion System," SAE Int. J. Eng., 2(1):20, 2009.

11. Leone, T. G., and Pozar, M., "Fuel Economy Benefit of Cylinder Deactivation - Sensitivity to Vehicle Application and Operating Constraints," SAE Technical Paper 2001-013591, 2001, Doi:10.4271/2001-01-3591.

12. Ayala, F.A., Gerty, M. D., and Heywood, J. B., "Effects of Combustion Phasing, Relative Air-fuel Ratio, Compression Ratio, and Load on SI Engine Efficiency," SAE Technical Paper 2006-01-0229, 2006; doi: 10.4271/2006-01-0229.

13. Leone, T., Olin, E., Anderson, J., Jung, H., et al., "Effects of Fuel Octane Rating and Ethanol Content on Knock, Fuel Economy, and $\mathrm{CO}_{2}$ for a Turbocharged DI Engine," SAE Int. J. Fuels Lubr. 7(1):2014, doi:10.4271/2014-01-1228.

14. Chow, E., Heywood, J., and Speth, R., "Benefits of a Higher Octane Standard Gasoline for the U.S. Light-Duty Vehicle Fleet," SAE Technical Paper 2014-01-1961, 2014, doi:10.4271/2014-01-1961.

15. Kalghatgi G.T., "Fuel Anti-Knock Quality - Part II. Vehicle Studies - How Relevant is Motor Octane Number in Modern Engines?" SAE Technical Paper 2001-01-3585, 2001, doi:10.4271/2001-01-3585.

16. Mittal V., and Heywood J., "The Shift in Relevance of Fuel RON and MON to Knock Onset in Modern SI Engines Over the Last 70 Years," SAE Int. J. Engines., 2(2), 2009, doi:10.4271/2009-01-2622.

17. Kalghatgi, G.T., "Fuel Engine Interactions," (Warren, PA, SAE International, 2013).

18. Mittal, V., and Heywood, J., "The Relevance of Fuel RON and MON to Knock Onset in Modern SI Engines," SAE Technical Paper 2008-01-2414, 2008, doi:10.4271/200801-2414.

(c) 2018 SAE International; Ford Motor Company; National Renewable Energy Laboratory. 
19. Wyszynski, L.P., Stone, C.R., and Kalghatgi, G.T., "The Volumetric Efficiency of Direct and Port Injection Gasoline Engines with Different Fuels," SAE Technical Paper 2002-010839, 2002, doi:10.4271/2002-01-0839.

20. Okamoto, K., Ichikawa, T., Saitoh, K., Oyama, K., et al., Study of Antiknock Performance Under Various Octane Numbers and Compression Ratios in a DISI Engine," SAE Technical Paper 2003-01-1804, 2003; DOI 10.4271/2003-01$\underline{1804 .}$.

21. Anderson, J.E., DiCicco, D.M., Ginder, J.M., Kramer, U. et al., "High Octane Number Ethanol-Gasoline Blends: Quantifying the Potential Benefits in the United States," Fuel 97:585-594, 2012.

22. Kasseris, E., and Heywood, J., "Charge Cooling Effects on Knock Limits in SI DI Engines Using Gasoline/Ethanol Blends: Part 1 - Quantifying Charge Cooling," SAE Technical Paper No. 2012-01-1275, 2012, doi:10.4271/2012-01-1275.

23. Kasseris, E., and Heywood, J., "Charge Cooling Effects on Knock Limits in SI DI Engines Using Gasoline/Ethanol Blends: Part 2 - Effective Octane Numbers," SAE Technical Paper 2012-01-1284, 2012, doi:10.4271/2012-01-1284.

24. Chupka, G.M., Christensen, E., Fouts, L., Alleman, T.L. et al., "Heat of Vaporization Measurements for Ethanol Blends up to 50 Volume Percent in Several Hydrocarbon Blendstocks and Implications for Knock in SI Engines," SAE Int. J. Fuels Lubr. 8(2):251-263, 2015, doi:10.4271/2015-01-0763.

25. Sluder, C.S., Szybist, J.P., Ratcliff, M.A., McCormick, R.L. et al., "Exploring the Relationship between Octane Sensitivity and Heat-of-Vaporization," SAE Int. J. Fuels Lubri. 9(1):80-90, 2016, doi:10.4271/2016-01-0836.

26. Stein, R.A., Polovina, D., Roth, K., Foster, M. et al., "Effect of Heat of Vaporization, Chemical Octane, and Sensitivity on Knock Limit for Ethanol - Gasoline Blends," SAE Int. J. Fuels Lubr. 5(2):823-843, 2012.

27. Wang, C., Janssen, A., Prakash, A., Cracknell, R. et al., "Splash Blended Ethanol in a Spark Ignition Engine - Effect of RON, Octane Sensitivity, and Charge Cooling," Fuel 196:21-31, 2017.

28. Foong, T., Morganti, K., Brear, M., da Silva, G., et al., "The Effect of Charge Cooling on the RON of Ethanol/Gasoline Blends," SAE Int. J. Fuels Lubr. 2013; 6(1), doi:10.4271/2013$\underline{01-0886}, 34,43$.

29. Thewes, M., Küpper, C., Rezaei, R., Pischinger, S., et al., "Future Fuels for Modern DISI Engines." In 19th Aachen Colloquium Automobile and Engine Technology, 539-570, 2010.

30. Vuilleumier, D. and Sjöberg, M., "Significance of RON, MON, and LTHR for Knock Limits of Compositionally Dissimilar Gasoline Fuels in a DISI Engine," SAE Int. J. Eng. 10(3), 2017, doi:10.4271/2017-01-0662.

31. Jung, H., Shelby, M., Newman, C., and Stein, R., "Effect of Ethanol on Part Load Thermal Efficiency and $\mathrm{CO}_{2}$ Emissions of SI Engines," SAE Int. J. Eng. 6(1):456-469, 2013, doi:10.4271/2013-01-1634.

32. Foong, T.M., Morganti, K.J., Brear, M.J., da Silva, G., et al., "The Octane Numbers of Ethanol Blended with Gasoline and its Surrogates." Fuel, 115:727-739, 2014.

33. Morgan, N., Smallbone, A., Bhave, A., Kraft, M. et al., "Mapping Surrogate Gasoline Compositions into RON/ MON Space," Combustion and Flame 157:1122-1131, 2010.
34. Ratcliff, M.A., Burton, J., Sindler, P., Christensen, E. et al., "Knock Resistance and Fine Particle Emissions for Several Biomass-Derived Oxygenates in a Direct-Injection SparkIgnition Engine," SAE Int. J. Fuels Lubr. 9(1):59-70, 2016, doi:10.4271/2016-01-0705.

35. McCormick, R.L., Ratcliff, M.A., Christensen, E., Fouts, L. et al., "Properties of Oxygenates Found in Upgraded Biomass Pyrolysis Oil as Components of Spark and Compression Ignition Engine Fuels," Energy and Fuels 29(4):24532461, 2015.

36. Cannella, W., Foster, M., Gunter, G., and Leppard, W., "FACE Gasolines and Blends with Ethanol: Detailed Characterization of Physical and Chemical Properties," CRC Report No. AVFL-24, July 2014.

37. He, X., Ratcliff, M.A., and Zigler, B.T., "Effects of Gasoline Direct Injection Engine Operating Parameters on Particle Number Emissions," Energy \& Fuels 26:2014-2027, 2012.

38. National Instruments, "Combustion Analysis System Software for LabVIEW User Manual,” 162. http://digital.ni. com/manuals.nsf/websearch/C2B04021AA306BBB86257BC D007365C6.

39. Gatowski, J. A., Balles, E. N., Chun, K. M., Nelson, F. E., et al., "Heat Release Analysis of Engine Pressure Data," SAE Technical Paper $\underline{841359}$, 1984, oi.org/10.4271/841359.

40. Cheung, H. M., and Heywood, J. B., "Evaluation of a OneZone Burn-Rate Analysis Procedure Using Production SI Engine Pressure Data," SAE Technical Paper 932749, 1993, doi.org/10.4271/932749.

41. Szybist, J.P. and Splitter, D.A., "Pressure and Temperature Effects on Fuels with Varying Octane Sensitivity at High Load in SI Engines," Combustion and Flame 177:49-66, 2017.

42. Kalghatgi, G., "Fuel Anti-Knock Quality - Part I. Engine Studies," SAE Technical Paper 2001-01-3584, 2001, doi: 10.4271/2001-01-3584.

43. Zhou, Z., Yi, Y., Brear, M., Lacey, J. et al., "A Comparison of four Methods for Determining the Octane Index and $K$ on a Modern Engine with Upstream, Port or Direct Injection," SAE Technical Paper 2017-01-0666, 2017, doi:10.4271/201701-0666.

44. Risberg, P., Kalghatgi, G.T., and Ångstrom, H.-E., "Autoignition Quality of Gasoline-Like Fuels in HCCI Engines," SAE Technical Paper 2003-01-3215, 2003, 10.4271/2003-01$\underline{3215}$.

45. Amer, A., Babiker, H., Chang, J., Kalghatgi, G. et al., "Fuel Effects on Knock in a Highly Boosted Direct Injection Spark Ignition Engine," SAE Int. J. Fuels Lubr. 5(3):1048-1065, 2012, doi:10.4271/2012-01-1634.

46. Tian, M., Haaren, R.V., Reijnders, J., and Boot, M., "Lignin Derivatives as Potential Octane Boosters," SAE Int. J. Fuels Lubr. 8(2), 2015, doi:10.4271/2015-01-0963.

47. Boot, M.D., Tian, M., Hensen, E.J.M., and Sarathy, S.M., "Impact of Fuel Molecular Structure on Auto-Ignition Behavior - Design Rules for Future High Performance Gasolines," Progress in Energy and Combustion Science 60:125, 2017.

48. Kolodziej, C.P. and Wallner, T., "Combustion Characteristics of Various Fuels during Research Octane Number Testing on an Instrumented CFR F1/F2 Engine," Combustion Engines 171(4):164-169, 2017. 


\section{Contact Information}

\section{Matthew Ratcliff}

matthew.ratcliff@nrel.gov

\section{Acknowledgments}

This research was conducted as part of the Co-Optimization of Fuels \& Engines (Co-Optima) project sponsored by the U.S. Department of Energy - Office of Energy Efficiency and Renewable Energy, Bioenergy Technologies and Vehicle Technologies Offices. Co-Optima is a collaborative project of several national laboratories initiated to simultaneously accelerate the introduction of affordable, scalable, and sustainable biofuels and high-efficiency, low-emission vehicle engines. The authors gratefully acknowledge the contributions to the combustion analysis by Brandon King from Colorado State University. Work at the National Renewable Energy Laboratory was performed under Contract No. DE347AC36-99GO10337. The U.S. Government retains and the publisher, by accepting the article for publication, acknowledges that the U.S. Government retains a nonexclusive, paid-up, irrevocable, worldwide license to publish or reproduce the published form of this work, or allow others to do so, for U.S. Government purposes.

\section{Definitions/Abbreviations}

$\Delta \mathrm{T}_{\mathrm{ad}}$ - adiabatic evaporative cooling temperature

aTDC - after top dead center

BOB - blendstock for oxygenate blending

CA50 - crank angle for 50\% mass fraction burned

CFR - Cooperative Fuels Research
C $\mathbf{p}_{\text {mixture }}$ - heat capacity at constant pressure of the fuel-air mixture

CR - compression ratio

DI - direct injection

FACE - Fuels for Advanced Combustion Engines

HOV - heat of vaporization, $\mathrm{kJ} / \mathrm{kg}$

IAT - intake air temperature

IMEP - indicated mean effective pressure

IVCT - intake valve closing temperature

$\boldsymbol{K}$ - empirical constant in octane index equation

KI - integrated knock, or knock-integral

$\mathbf{m}_{\text {air }}$ - mass of air

$\mathbf{m}_{\text {fuel }}$ - mass of fuel

MBT - minimum advance for best torque

MON - motor octane number

NMEP - net mean effective pressure

OI - octane index

PFI - port fuel injection

P-T - pressure-temperature

RON - research octane number

S - octane sensitivity (RON - MON)

SI - spark-ignition

$\mathbf{T}_{\text {comp15 }}$ - temperature when the pressure reaches 15 bar during the compression stroke

TRF - toluene research fuel

TSF - toluene standardization fuel

UI - upstream fuel injection

vol\% - percent by volume 


\section{Appendix}

\section{FIGURE A-1 Cylinder pressure data at IAT $=35^{\circ} \mathrm{C}$.}

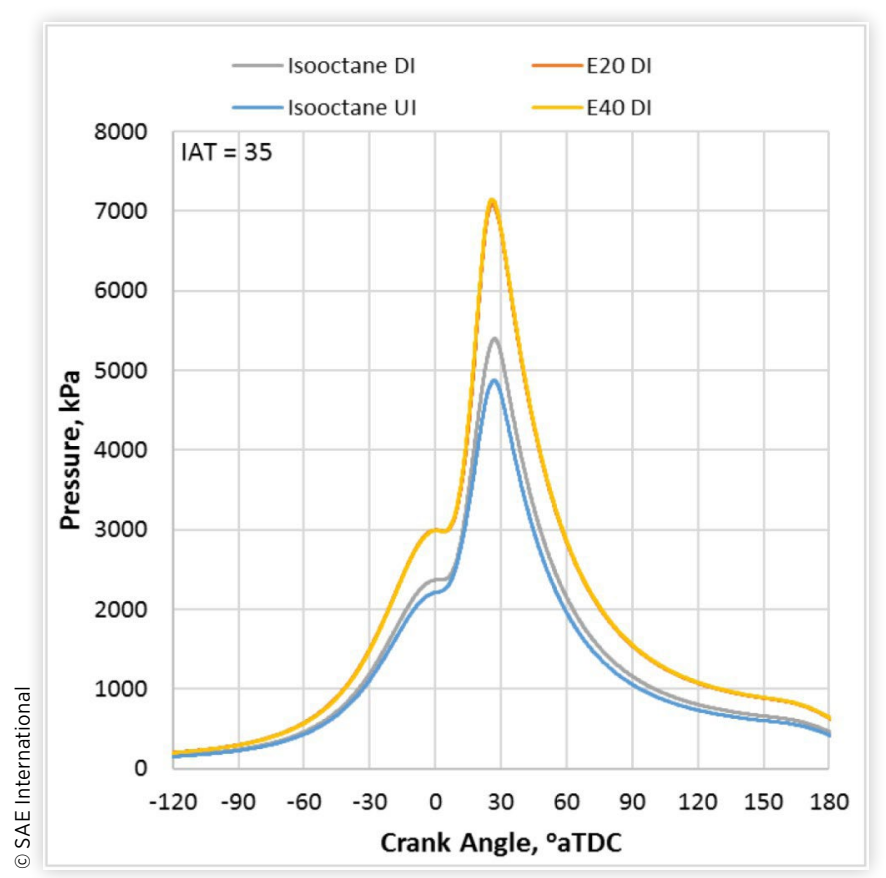

FIGURE A-2 Cylinder pressure data for IAT $=50^{\circ}$.

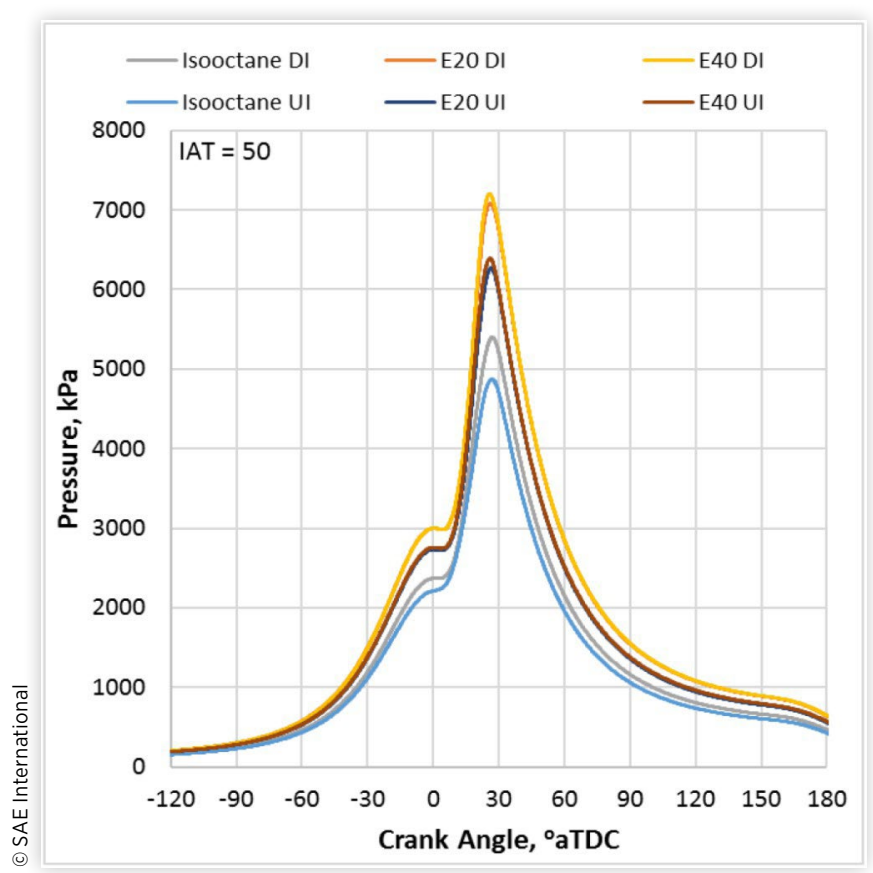

FIGURE A-3 Cylinder pressure data for IAT $=75^{\circ} \mathrm{C}$.

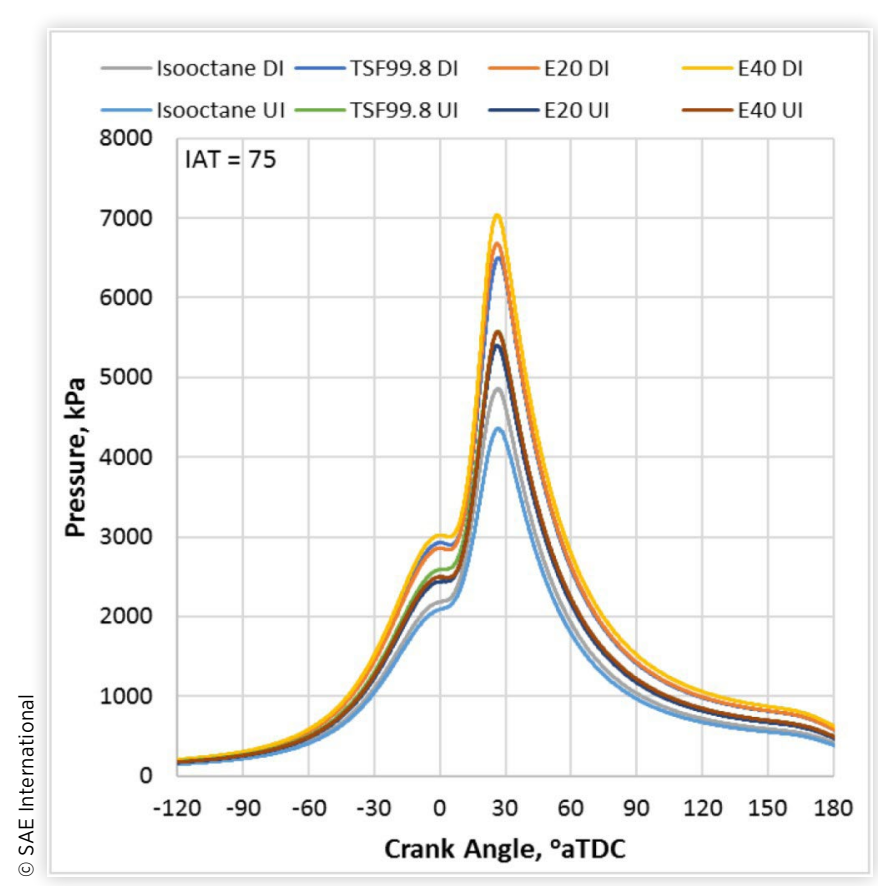


FIGURE A-4 Apparent heat release rate for IAT $=35^{\circ} \mathrm{C}$.
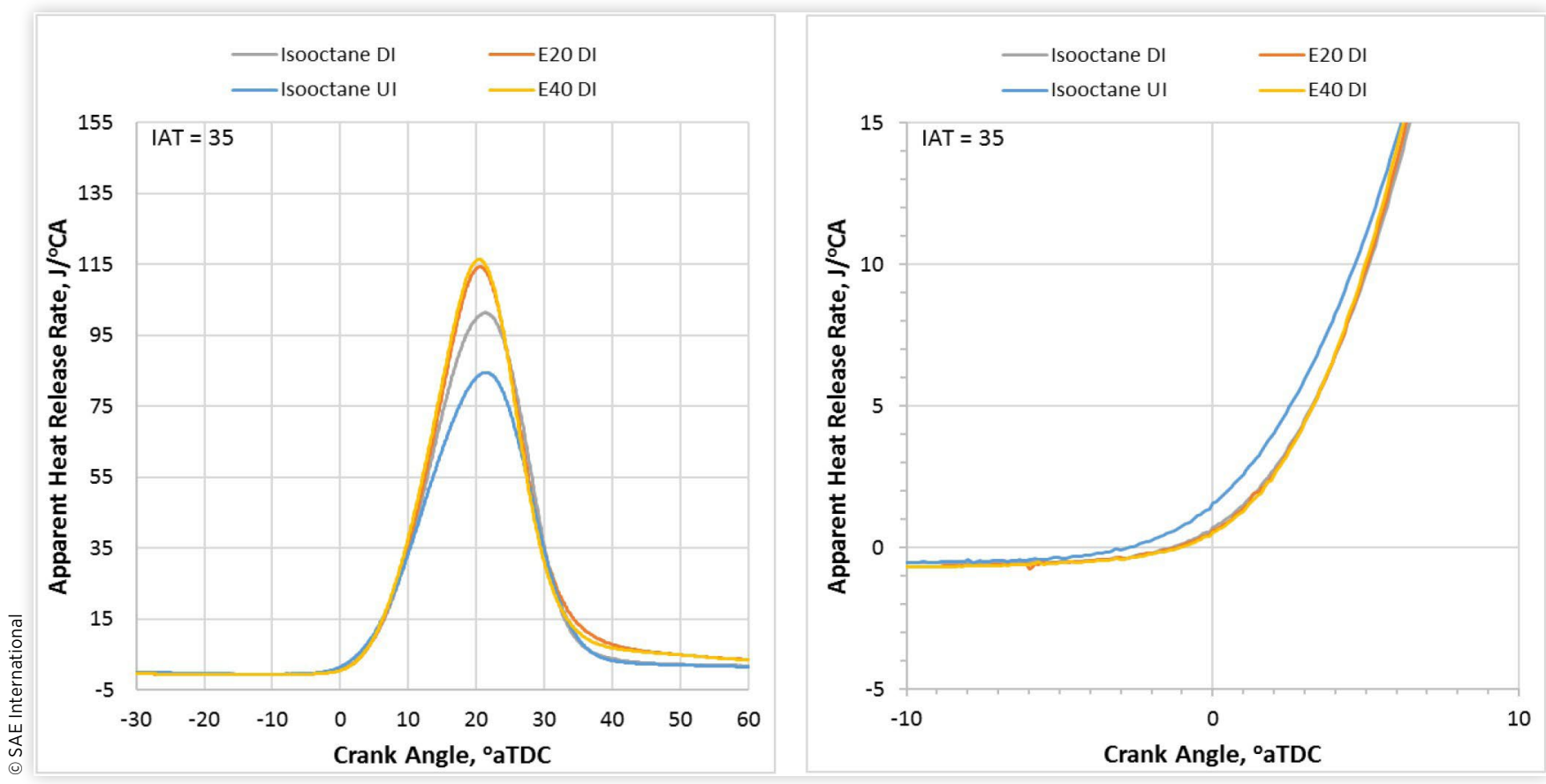

FIGURE A-5 Apparent heat release rate for $I A T=50^{\circ} \mathrm{C}$.
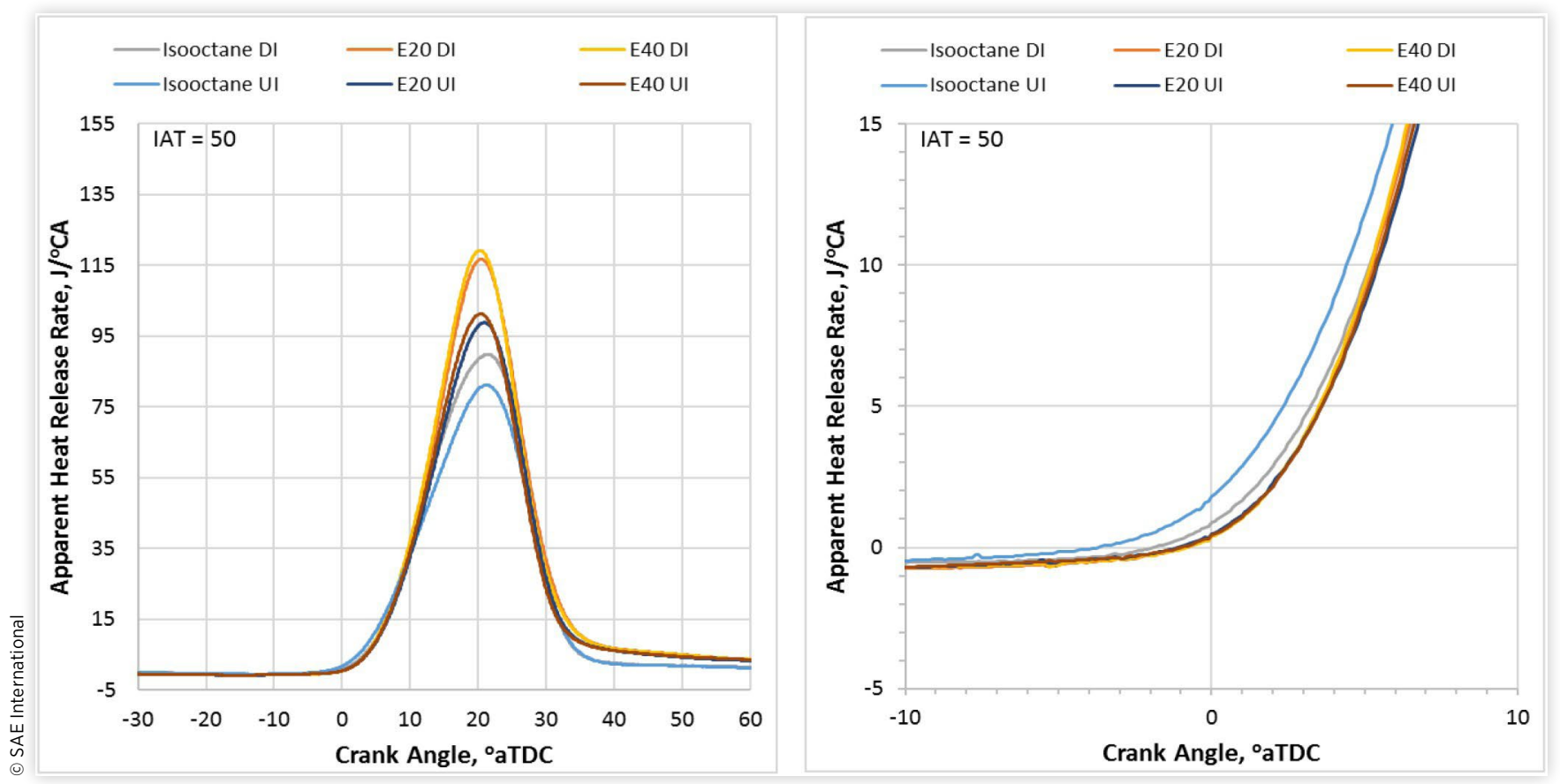
FIGURE A-6 Apparent heat release rate for IAT $=75^{\circ} \mathrm{C}$.

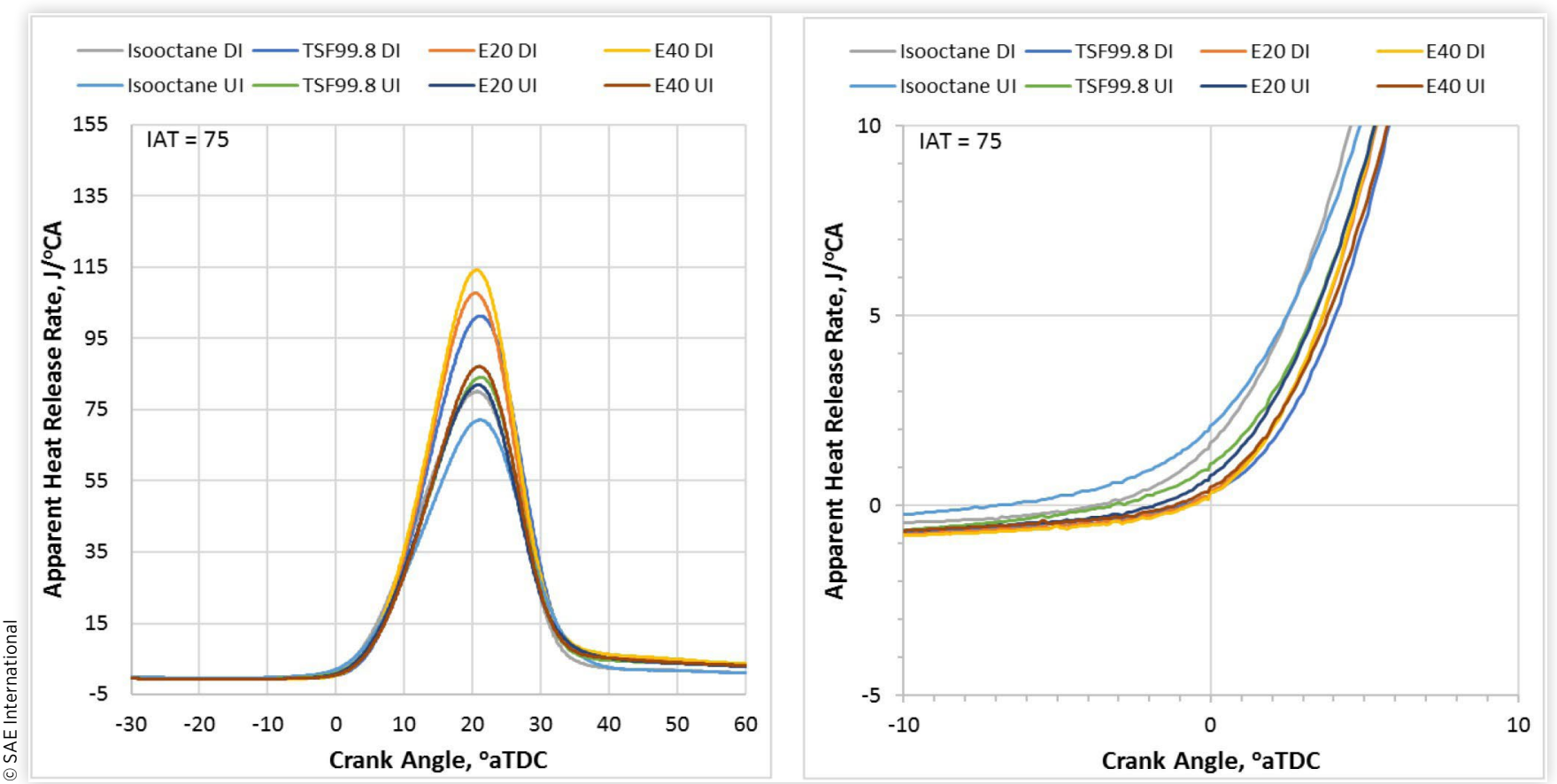

TABLE A-1 Calculated $K$ and OI values for DI runs. $K$ estimated using $T_{\text {comp15 }}$ calculated using assumed evaporative cooling. Subscript "ideal" indicates IVCT calculated from ideal gas law. Subscript " $\Delta$ Tad" indicates IVCT calculated as IAT less $70 \%$ of $\Delta$ Tad.

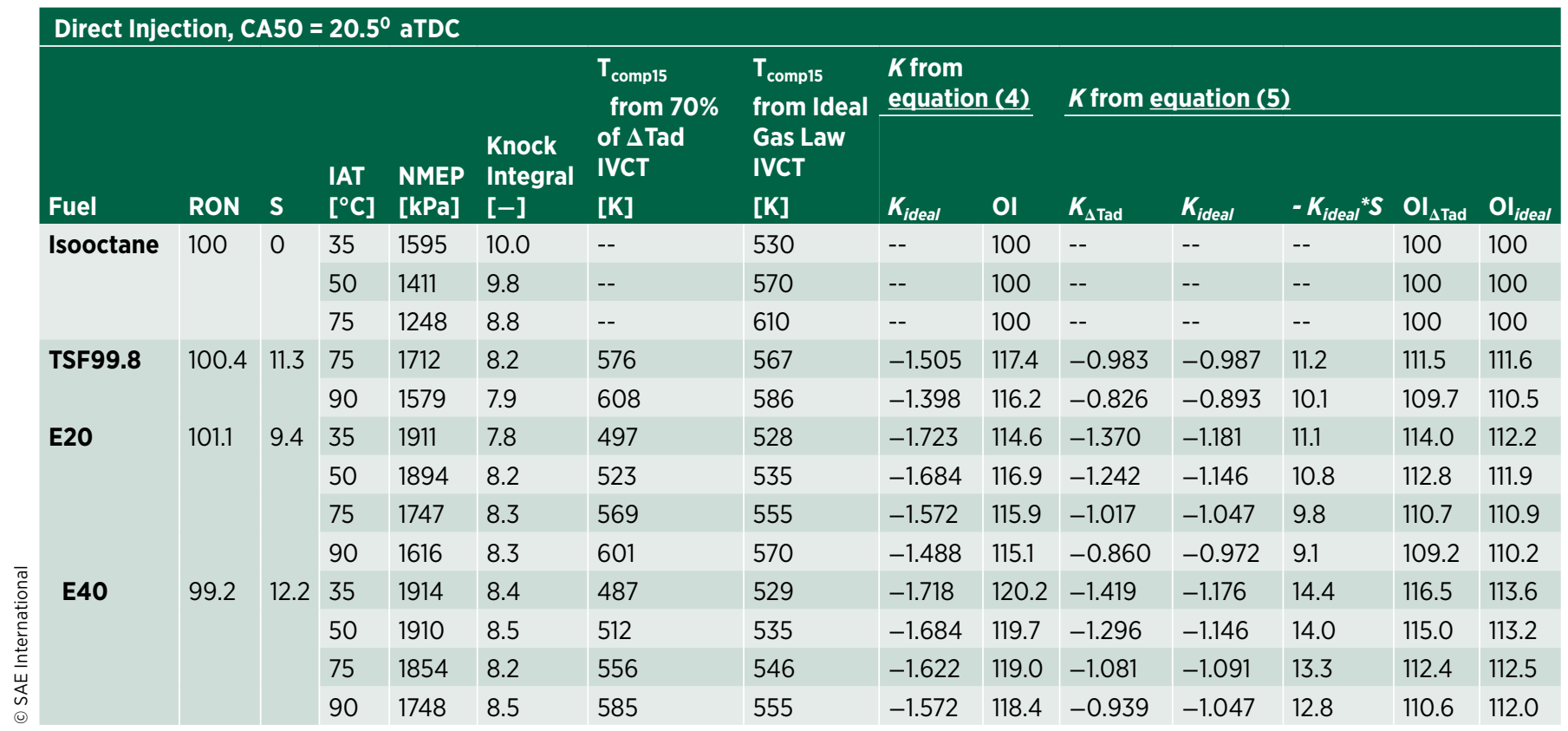


TABLE A-2 Calculated $K$ and OI values for UI runs. $T_{\text {comp15 }}$ calculated using the assumption IVCT = IAT.

\begin{tabular}{|c|c|c|c|c|c|c|c|c|c|c|c|}
\hline \multirow[b]{2}{*}{ Fuel } & \multirow[b]{2}{*}{ RON } & & \multirow[b]{2}{*}{ IAT $\left[{ }^{\circ} \mathrm{C}\right]$} & \multirow[b]{2}{*}{$\begin{array}{l}\text { NMEP } \\
\text { [kPa] }\end{array}$} & \multirow{2}{*}{$\begin{array}{l}\text { Knock } \\
\text { Integral } \\
{[-]}\end{array}$} & \multirow{2}{*}{$\begin{array}{l}T_{\text {comp15 }} \\
\text { [K] }\end{array}$} & \multicolumn{2}{|c|}{$K$ from equation (4) } & \multicolumn{3}{|c|}{$K$ from equation (5) } \\
\hline & & $\mathbf{S}$ & & & & & $K$ & 이 & $K$ & $-\boldsymbol{K}^{*} \boldsymbol{S}$ & OI \\
\hline \multirow[t]{2}{*}{ Isooctane } & \multirow[t]{2}{*}{100} & \multirow[t]{2}{*}{0} & 35 & 1389 & 8.5 & 550 & -- & 100 & -- & -- & 100 \\
\hline & & & 50 & 1270 & 9.4 & 585 & -- & 100 & -- & -- & 100 \\
\hline \multirow[t]{2}{*}{ TSF99.8 } & \multirow[t]{2}{*}{100.4} & \multirow[t]{2}{*}{11} & 75 & 1443 & 8.6 & 611 & -1.26 & 114.6 & -0.81 & 9.2 & 109.6 \\
\hline & & & 90 & 1400 & 8.4 & 640 & -1.10 & 112.8 & -0.67 & 7.6 & 108.0 \\
\hline \multirow[t]{3}{*}{ E20 } & \multirow[t]{3}{*}{101.1} & \multirow[t]{3}{*}{9} & 50 & 1648 & 8.2 & 563 & -1.53 & 115.5 & -1.05 & 9.8 & 110.9 \\
\hline & & & 75 & 1407 & 7.9 & 614 & -1.24 & 112.8 & -0.80 & 7.5 & 108.6 \\
\hline & & & 90 & 1317 & 8.3 & 644 & -1.07 & 111.2 & -0.65 & 6.1 & 107.2 \\
\hline \multirow[t]{2}{*}{ E40 } & \multirow[t]{2}{*}{99.2} & \multirow[t]{2}{*}{12} & 50 & 1666 & 8.6 & 562 & -1.53 & 117.9 & -1.05 & 12.8 & 112.0 \\
\hline & & & 75 & 1449 & 8.7 & 611 & -1.26 & 114.6 & -0.81 & 9.9 & 109.1 \\
\hline
\end{tabular}

TABLE A-3 Calculation of $K$ for the RON test with ethanol blends using data from reference 32 . mRON = Modified RON. $\mathrm{mS}=\mathrm{mRON}-\mathrm{MON} . K=(\mathrm{mRON}-\mathrm{RON}) / \mathrm{mS}$.

\begin{tabular}{|c|c|c|c|c|c|c|c|c|c|}
\hline \multirow{6}{*}{ 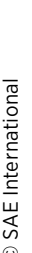 } & Fuel & RON & mRON & Standard IAT & Modified IAT & MON & $\mathbf{S}$ & $\mathrm{ms}$ & $K$ \\
\hline & PRF100-E10 & 106.8 & 106.8 & 51.7 & 58 & 99.9 & 6.9 & 6.9 & 0 \\
\hline & PRF100-E20 & 109.4 & 108.9 & 51.7 & 64 & 99.1 & 10.3 & 9.8 & -0.051 \\
\hline & PRF100-E40 & 110.2 & 108.2 & 51.7 & 89 & 95.9 & 14.3 & 12.3 & -0.163 \\
\hline & PRF100-E60 & 109.6 & 107.1 & 51.7 & 114 & 94.2 & 15.4 & 12.9 & -0.194 \\
\hline & PRF100-E80 & 109 & 105.1 & 51.7 & 140 & 92.6 & 16.4 & 12.5 & -0.312 \\
\hline
\end{tabular}

This is the work of a Government and is not subject to copyright protection. Foreign copyrights may apply. The Government under which this paper was written assumes no liability or responsibility for the contents of this paper or the use of this paper, nor is it endorsing any manufacturers, products, or services cited herein and any trade name that may appear in the paper has been included only because it is essential to the contents of the paper.

Positions and opinions advanced in this paper are those of the author(s) and not necessarily those of SAE International. The author is solely responsible for the content of the paper. 